\title{
anatomy
}

Teaching Anatomy

www.anatomy.org.tr

Received: May 13, 2020; Accepted: Fuly 22, 2020

doi:10.2399/ana.20.045

\section{Anatomy education in traditional and complementary medicine: who should teach anatomy?}

\author{
Cüneyt Bozer (iD \\ Department of Anatomy, School of Medicine, Trakya University, Edirne, Turkey
}

\begin{abstract}
Objectives: The aim of this study was to emphasize the amount of anatomy courses in the regulation titled, "Traditional and Complementary Medical Implementations" and to make anatomists think of the question who should teach anatomy in traditional and complementary medicine?

Methods: The anatomy courses in the standards of education for traditional and complementary therapies organized by the Turkish Republic Ministry of Health were investigated. The number of anatomy courses for teaching complementary medicine without standards of education were taken from the draft regulation for traditional and complementary therapies.

Results: Clinical anatomy is the practical application of anatomical knowledge to diagnosis and treatment. Up to date, there is no regulation defining who is authorized to give anatomy lectures in the workshops or courses permitted by the Ministry of Health of Turkey. It was seen that, theoretically, any health practitioner in workshops could give anatomy lectures.

Conclusion: Anatomists are experts of the structure and relationship of all parts of the body. A great number of anatomists are practicing traditional and complementary medicine in Turkey. The anatomists who are qualified in both anatomy and complementary medicine may be the ideal lecturers in the education of these methods.
\end{abstract}

Keywords: anatomy; complementary; education; medicine; traditional

Anatomy 2020;14(3):198-201 (2020 Turkish Society of Anatomy and Clinical Anatomy (TSACA)

"Doctors without anatomy are like moles: they work in the dark and their daily tasks are mole bills"-German anatomist and physiologist

Friedrich Tiedemann

\section{Introduction}

Anatomy has been a keystone in medical education throughout history. For medical doctors, the human body is the focus of investigation and intervention on a daily basis. ${ }^{[1]}$ For this reason, the study of anatomy in some form will continue to be essential to safe medical practice. The knowledge of anatomy is necessary for all doctors to practice safely. ${ }^{[1,2]}$

Since 1990's The World Health Organization (WHO) has supported "Traditional and Complementary Medicine" in terms of practice and research primarily in the universities. In recent years, traditional and complementary medical therapies have come into clinical practice in developed countries. Traditional and complementary therapies have also gained importance in our country due to its wide health benefits, safety and minimal side effects compared to chemical agents. Recently, the Ministry of Health constituted the Department of Traditional and Complementary Medicine for determining the traditional and complementary therapies, setting standards for education of these therapy methods, standardization of the education levels of the practitioners and determining the ethical issues and legal liabilities. A regulation has been published by the Turkish Ministry of Health to regulate the certifications of traditional and complementary medicine practitioners with the

This study was a poster presentation at 16th National Anatomy Congress, September 11-14, 2014, Malatya, Turkey. 
aim of reducing health costs in Turkey. ${ }^{[3]}$ The government introduced a regulation for establishment of Turkish National Institute for Traditional and Complementary Medicine. ${ }^{[4]}$

In the regulation titled "Traditional and Complementary Medical Implementations (Geleneksel ve Tamamlayıcı Tıp Uygulamaları Yönetmeliği)”, the therapy methods regulated by the Turkish Republic Ministry of Health are acupuncture, apitherapy, phytotherapy, hypnosis, hirudotherapy, homeopathy, chiropractic, cupping, maggot therapy, mesotherapy, prolotherapy, osteopathy, ozone therapy, reflexology, and musical therapy. The regulation also sets out the curriculum of these therapy methods. ${ }^{[3]}$

Anatomy constitutes an important part in the acupuncture, chiropractic, prolotherapy and osteopathy trainings. ${ }^{[5,6]}$ However there is not a standard telling the content and amount of the anatomy lectures.

The aim of this study was to emphasize the amount of anatomy courses in the regulation titled, "Traditional and Complementary Medical Implementations" and to make anatomists think of the question "who should teach anatomy in traditional and complementary medicine?"

\section{Materials and Methods}

The anatomy courses in the standards of education for traditional and complementary therapies were investigated in the Traditional and Complementary Medical Implementations of the Turkish Republic Ministry of Health. The amount of anatomy courses in complementary methods without standards of education were taken from the draft regulation for traditional and complementary therapies.

\section{Results}

In the education standards of traditional and complementary medicine methods, there are anatomy courses related to topographic anatomy, spinal anatomy, radiographic anatomy, neuroanatomy, functional anatomy, and anatomy of the locomotor system (Tables 1 and 2). ${ }^{[7-18]}$

Table 1 provides a summary of the anatomy courses and their hours for the physicians. In the curriculum of acupuncture, the hours of anatomy courses are not mentioned in modules 1 and 6 . The total hours for module 1 were 30 and the total hours for module 6 are $80 .{ }^{[7]}$ In apitherapy, there were 2 hours of topographic anatomy. ${ }^{[8]}$ For osteopaths, the knowledge of the anatomy of nervous, locomotor and lymphatic system is crucial. Correspondingly, the courses of functional anatomy, neuroanatomy and anatomy of the lymphatic system were included in the curriculum for 10, 10 and 5 hours respectively. ${ }^{[9]}$ In the curriculum of ozone therapy skin anatomy and physiology is included in total 16 hours of the module $6 .^{[10]}$ In prolotherapy, which is an interventional therapy method, the functional anatomy of joints, connective tissue, ligaments, and tissues took part in module 1 consisted of 8 hours. ${ }^{[1]}$ And finally, 4 hours of neuroanatomy and neurophysiology was planned for the reflexology course attendees. ${ }^{[12]}$

In the draft regulation, assistant health professionals should take 30 hours of anatomy, 25 hours of neuroanatomy and 70 hours of spinal anatomy for chiropractic certification. In reflexology education, there were introduction to anatomy and physiology for 4 hours and human anatomy and systems for 10 hours. A total of 35 hours of basic and functional anatomy, 25 hours of neuroanatomy and 30 hours of spinal anatomy and biomechanics was planned for

Table 1

Anatomy courses in the traditional and complementary medicine education for physicians.

\begin{tabular}{|c|c|c|}
\hline TCM method & Total hours of anatomy lectures & Content of the anatomy course \\
\hline Acupuncture & ? (Module 1: 30 hours) & Topographic anatomy \\
\hline Ear acupuncture (in acupuncture) & ? (Module 6: 80 hours) & Ear anatomy \\
\hline Apitherapy & 2 & Topographic anatomy \\
\hline \multirow[t]{3}{*}{ Chiropractic } & 10 & Spinal anatomy \\
\hline & 9 & Normal radiological anatomy \\
\hline & 10 & Neuroanatomy \\
\hline Ozone therapy & ? (Module 6: 16 hours) & Skin anatomy and physiology \\
\hline Prolotherapy & ? (Module 1: 8 hours) & $\begin{array}{c}\text { Functional anatomy of joints, connective } \\
\text { tissue, ligaments and muscles }\end{array}$ \\
\hline Reflexology & 4 & Neuroanatomy (with neurophysiology) \\
\hline \multirow[t]{2}{*}{ Osteopathy } & 10 & Functional anatomy \\
\hline & 5 & Neuroanatomy \\
\hline
\end{tabular}

TCM: traditional and complementary medicine; ?: unspecified hours of anatomy lectures. 
osteopathy training. Table 2 provides a summary of the anatomy courses and their hours for the assistant health professionals. $^{[13]}$

\section{Discussion}

Knowledge of anatomy is essential for all health care professionals. Especially in acupuncture, chiropractic, prolotherapy and osteopathy trainings knowledge of anatomy is crucial to apply proper therapy. In acupuncture, the therapist should always know where the tip of their needle lies with respect to the relevant anatomy so that injury to the vital structures can be avoided and the main target for stimulation can be reached. ${ }^{[5,6]}$ A prolotherapist should know the anatomy of the region to be treated in order to protect the vital structures during injections. Chiropractors and osteopaths should have a strong knowledge of neuroanatomy and spinal anatomy so as not to cause damage to the patient.

Anatomists are the experts of the structure and relationship of all parts of the body and clinical anatomy is the practical application of anatomical knowledge to diagnosis and treatment. The education staff in most of the training courses do not involve any anatomists who are certified in traditional and complementary medicine. A lack of adequate anatomy training in education of traditional and complementary methods will restrain the progress of the course attendee. Trainees educated by an anatomist with a knowledge of clinical anatomy in traditional and complementary therapies can implement these methods successfully.

The amount of anatomy courses in the standards of education for traditional and complementary therapies was investigated in this viewpoint. The amount of anatomy courses in complementary methods without standards of education were taken from the draft regulation for traditional and complementary therapies. The education stan- dards of the chiropractic have not been published yet. Based on the draft regulation of Traditional and Complementary Medical Implementations, anatomy education is planned to be given in three different courses in the training of chiropractic. ${ }^{[13]}$ The curriculum of chiropractic for physicians was planned as 10 hours of education for spinal anatomy, 9 hours for normal radiographic anatomy and 10 hours for neuroanatomy.

According to the draft regulation, the assistant health professionals can attend to the courses of chiropractic, reflexology, osteopathy, and cupping therapy. ${ }^{[13]}$ However, they can perform the methods under the supervision of a certificated physician. Since the publication of the draft regulation there has been no training for the assistant health professionals.

\section{Conclusion}

In Turkey, some private and state universities have constituted research and education centers under different titles for traditional and complementary medicine. The anatomy education takes an important part in the workshops or courses of these therapy methods. Anatomy education is obviously essential for any health practitioner who performs an invasive procedure on a patient. According to anecdotal evidence gathered in the field, long-term retention of anatomy knowledge may be deficient. Anatomy education is an important element of the medical curriculums of the traditional and complementary medicine trainings. But the point is by whom these anatomy lectures would be given. The answer of this question is not specified in the regulations. A great number of anatomists have certified in traditional and complementary medicine in Turkey. The anatomists who are qualified both in anatomy and complementary medicine may be the ideal lecturers in the education of these methods.

Table 2

Anatomy courses in the traditional and complementary medicine education for assistant health professionals.

\begin{tabular}{|c|c|c|}
\hline TCM method & Total hours of anatomy lectures & Content of the anatomy course \\
\hline \multirow[t]{3}{*}{ Chiropractic } & 30 & Anatomy \\
\hline & 25 & Neuroanatomy \\
\hline & $30+40$ & Spinal anatomy \\
\hline \multirow[t]{2}{*}{ Reflexology } & 4 & Introduction to anatomy and physiology \\
\hline & 10 & Human anatomy and systems \\
\hline \multirow[t]{3}{*}{ Osteopathy } & 35 & Basic and functional anatomy \\
\hline & 25 & Neuroanatomy \\
\hline & 30 & Spinal anatomy and biomechanics \\
\hline
\end{tabular}

TCM: traditional and complementary medicine. 
The shortage of cadavers is a main problem for all anatomy departments in Turkey. Some departments solve this problem by organizing cadaver workshops on imported cadavers with the surgical departments. After the workshops, the cadavers can be used for undergraduate and postgraduate education in these departments. There is an increasing number of complementary medicine workshops. Especially for the invasive methods, anatomy training on cadavers is popular. A secondary benefit for anatomy departments is providing cadavers for education.

New and different fields of education and employment may develop for the Turkish anatomists if the anatomists will be authorized for anatomy education in traditional and complementary medicine. The Turkish Society of Anatomy and Clinical Anatomy can vindicate the benefits of anatomists in the education of anatomy in traditional and complementary medicine.

\section{Conflict of Interest}

The author declares that there is no conflict of interest.

\section{Ethics Approval}

Ethics approval was not required since the study was not performed in humans or animals and no personal data was used.

\section{Funding}

The author did not receive funding for designing, conducting, or writing of the study.

\section{References}

1. Turney BW. Anatomy in a modern medical curriculum. Ann R Coll Surg Engl 2007;89:104-7.

2. Sugand K, Abrahams P, Khurana A. The anatomy of anatomy: a review for its modernization. Anat Sci Educ 2010;3:83-93.

3. Geleneksel ve Tamamlayıcı Tip Uygulamaları Yönetmeliği. [Internet]. [Retrieved on May 26, 2020]. Available from: https:// www.resmigazete.gov.tr/eskiler/2014/10/20141027-3.htm

ORCID ID:

C. Bozer 0000-0002-2001-6056

\section{deomed.}

4. Türkiye Sağlık Enstitüleri Başkanlığı Kurulması ile Bazı Kanun ve Kanun Hükmünde Kararnamelerde Değişiklik Yapılmasına Dair Kanun. [Internet]. [Retrieved on May 26, 2020]. Available from: http://www.resmigazete.gov.tr/eskiler/2014/11/20141126-3.htm

5. Peuker ET, White A, Ernst E, Pera F, Filler TJ. Traumatic complications of acupuncture. Therapists need to know human anatomy. Arch Fam Med 1999;8:553-8.

6. Peuker E, Cummings M. Anatomy for the acupuncturist-facts \& fiction 1: the head and neck region. Acupunct Med 2003;21:2-8.

7. Standards of Education for Acupuncture. [Internet]. [Retrieved on May 26, 2020]. Available from: http://dosyasb.saglik.gov.tr/Eklenti/ 3971, akupunktur-egitim-standartlari-imzalananpdf.pdf

8. Standards of Education for Apitherapy. [Internet]. [Retrieved on May 26, 2020]. Available from: http://dosyasb.saglik.gov.tr/Eklenti/ 3981,apiterapi-sertifikali-egitim-standartlaripdf.pdf

9. Standards of Education for Osteopathy. [Internet]. [Retrieved on May 26, 2020]. Available from: http://www.istanbulsaglik.gov.tr/w/sb/ duyurular/belge/osteopati_28112016.pdf

10. Standards of Education for Ozone Therapy. [Internet]. [Retrieved on May 26, 2020]. Available from: http://dosyasb.saglik.gov.tr/ Eklenti/3973,ozon-uygulamasi-sep-standartlaripdf.pdf

11. Standards of Education for Prolotherapy. [Internet]. [Retrieved on May 26, 2020]. Available from: https://dosyasb.saglik.gov.tr/Eklenti/ 3986,proloterapi-sertifikali-egitim-standartlaripdf.pdf

12. Standards of Education for Reflexology. [Internet]. [Retrieved on May 26, 2020]. Available from: http://istanbulsaglik.gov.tr/w/sb/ duyurular/belge/refleksoloji_standart_sertf_egit_24112016.pdf

13. Sağglık Bakanlığı. Geleneksel, Tamamlayıcı ve Alternatif Tip Uygulamaları Yönetmeliği Taslak Metni. [Internet]. [Retrieved on May 26, 2020]. Available from: https://www.memurlar.net/ common/news/documents/451139/gtat-yonetmelik-taslagi.pdf

14. Standards of Education for Phytotherapy. [Internet]. [Retrieved on May 26, 2020]. Available from: http://dosyasb.saglik.gov.tr/Eklenti/ 3972, fitoterapi-sep---pdfpdf.pdf

15. Standards of Education for Hypnosis. [Internet]. [Retrieved on May 26, 2020]. Available from: http://dosyasb.saglik.gov.tr/Eklenti/3983, hipnoz-sertifikali-egitim-standardipdf.pdf

16. Standards of Education for Homeopathy. [Internet]. [Retrieved on May 26, 2020]. Available from: http://dosyasb.saglik.gov.tr/Eklenti/ 3974,homeopati-sertifikali-egitim-standartlaripdf.pdf

17. Standards of Education for Cupping Therapy. [Internet]. [Retrieved on May 26, 2020]. Available from: http://dosyasb.saglik.gov.tr/ Eklenti/3976,kupa-uygulamasi-sep-standartlari-1pdf.pdf

18. Standards of Education for Maggot Therapy. [Internet]. [Retrieved on May 26, 2020]. Available from: http://dosyasb.saglik.gov.tr/ Eklenti/3992,larvapdf.pdf

Correspondence to: Cüneyt Bozer, MD, PhD, Assist. Prof. Department of Anatomy, School of Medicine, Trakya University, Balkan Campus, 22030, Edirne, Turkey

Phone: +902842355935

e-mail: cuneytbozer@trakya.edu.tr

Conflict of interest statement: No conflicts declared.

This is an open access article distributed under the terms of the Creative Commons Attribution-NonCommercial-NoDerivs 4.0 Unported (CC BY-NCND4.0) Licence (http://creativecommons.org/licenses/by-nc-nd/4.0/) which permits unrestricted noncommercial use, distribution, and reproduction in any medium, provided the original work is properly cited. How to cite this article: Bozer C. Anatomy education in traditional and complementary medicine: who should teach anatomy? Anatomy 2020;14(3):198-201. 